\title{
Chemical elements in the water of the São Pedro river basin, Faxinal - Paraná
}

\section{Elementos químicos nas águas da bacia do rio São Pedro, Faxinal - Paraná}

\author{
Cláudia Maria Justus ${ }^{1 *}$; Amarildo Pasini²; Jaqueline Aparecida Raminelli³; Leandro \\ Simões Azeredo Gonçalves ${ }^{2}$; André Celligoi ${ }^{4}$
}

\section{Highlights:}

Chemical elements were assessed in the water of the São Pedro river basin, in Faxinal-PR.

$\mathrm{Mn}, \mathrm{Al}$, and $\mathrm{Hg}$ were above the standards established by the Brazilian legislation.

The geology of the area may be interfering with the concentration of these substances.

\begin{abstract}
Anthropogenic activities close to water bodies can be sources of contamination, posing a risk to the environment and human health. This study aimed to assess the chemical composition of surface and groundwater samples collected from the São Pedro river basin, in the municipality of Faxinal (PRBrazil). Thirty-eight samples were collected in total: nineteen from rivers, two in dams, eleven at sites with springs, one in a shallow well, and five in deep wells part of the Guarani Aquifer System. Samples were collected in the rainy and dry seasons to determine the concentrations of the following elements: Magnesium, Copper, Manganese, Zinc, Chromium, Nickel, Aluminum, Lead, Mercury, and Cadmium, which were quantified using atomic absorption spectrometry (AAS) and atomic emission spectrometry (ICP-MS). The results were compared with the standards established by the Brazilian Ministry of Health Ordinance n. 2914/2011, which regulates the drinking water standard for human consumption in Brazil. Manganese, Aluminum, and Mercury levels were observed to be above those required by the standards established by the legislation, indicating that further studies are necessary to detect possible sources of pollution in these waters as well as highlighting the potential risks to human health and ultimately contributing to the environmental planning of this basin.
\end{abstract}

Key words: Heavy metals. Watershed. Water contamination.

\section{Resumo}

As atividades antrópicas localizadas muito próximas aos cursos d'água podem causar contaminação dos mesmos, oferecendo riscos ao meio ambiente e à saúde humana. Neste sentido, objetivou-se avaliar a composição química das águas superficiais e subterrâneas coletadas da bacia do rio São Pedro, em

1 Discente do Curso de Doutorado do Programa de Pós-Graduação em Agronomia, Universidade Estadual de Londrina, UEL, Londrina, PR, Brasil. E-mail: cmjustus@yahoo.com.br

2 Profs. Drs., Departamento de Agronomia, Programa de Pós-Graduação em Agronomia, UEL, Londrina, PR, Brasil. E-mail: pasini@uel.br; leandrosag@uel.br

3 Prof ${ }^{a}$ Dra, Departamento de Estatística, Programa de Pós-Graduação em Estatística, UEL, Londrina, PR, Brasil. E-mail: raminelli@uel.br

4 Prof. Dr., Departamento de Geociências, Programa de Pós-Graduação em Geografia, UEL, Londrina, PR, Brasil. E-mail: celligoi@uel.br

* Author for correspondence 
Faxinal (PR-Brasil). Foram coletadas 38 amostras no total: 19 amostras em rios, duas em represas, 11 em nascentes, uma em poço raso e cinco em poços tubulares profundos do Sistema Aquífero Guarani. As amostras foram coletadas nas estações chuvosa e seca para determinar a concentração dos seguintes elementos: Magnésio, Cobre, Manganês, Zinco, Cromo, Níquel, Alumínio, Chumbo, Mercúrio e Cádmio, as quais foram quantificadas por meio de espectrometria de absorção atômica (AAS) e espectrometria de emissão atômica (ICP-MS). Os resultados foram comparados com os padrões estabelecidos pela Portaria 2914 do Ministério da Saúde, que regula o padrão de potabilidade das águas para consumo humano no Brasil. Foram observados níveis de Manganês, Alumínio e Mercúrio acima dos padrões estabelecidos pela legislação, apontando que estudos complementares são necessários para detectar possíveis fontes poluidoras nestas águas, bem como sinalizar potenciais riscos à saúde humana e, assim, contribuir para o planejamento ambiental da referida bacia.

Palavras-chave: Metais pesados. Bacia hidrográfica. Contaminação hídrica.

In rural areas, the deterioration in water quality is particularly associated with intensive land use and poor agricultural management, resulting in toxic substances contaminating the adjacent water bodies. Studies conducted to evaluate the concentrations of these contaminants have reported a significant increase in the levels of residue associated with the use of agrochemicals (Chiarello et al., 2017).

In the state of Paraná (Brazil), traditionally characterized by varied agricultural activities, the monitoring of toxic chemical compounds (e.g., metals) has indicated that one of the possible sources of these substances can be the use of pesticides or even fertilizers that contain these substances, the presence of which are later reflected in nearby sources of water (Freire, Schneider, Hernandes de Freitas, Bonifácio, \& Granhen Tavares, 2012). More specifically, in the municipality of Faxinal (PRBrazil), due to the diversity of agricultural crops, the surface and groundwater from the São Pedro river basin may be exposed to heavy discharges of pollutants of anthropogenic origin, namely pesticides. In a study on the presence of pesticides in water bodies near agricultural areas of the state of Paraná, Vieira et al. (2016) detected concentrations above those permitted by the Brazilian legislation, particularly regarding DDT and its metabolites.

Given the varied risks to human health posed by heavy metal exposure and long term ingestion as well as the strong agricultural character of the area enclosing the municipality of Faxinal (PR-Brazil), our study aimed to evaluate the concentration of some of these elements in surface water and groundwater of the São Pedro river basin, in order to determine if the levels found conform to the standards set by the Brazilian Ministry of Health Ordinance 2914/2011 (Portaria n. 2914, 2011).

The study area (Figure 1) is encompassed by the rectangle, with the upper left and lower right vertices representing point A (UTM-N: 7,346,277, UTM-E: 465,897) and B (UTM-N: 7,351,365 and UTM-E: 471,654), respectively.

This region is occupied by rural properties developing different agricultural crops, especially wheat and oat during the winter, transitioning to soy and corn during the summer. In addition to the cultivation of grains, irrigated tomatoes are cultivated in greenhouses throughout the year. The region is also marked by cattle and poultry farming as well as reforestation areas, among other uses (characterized in Figure 1).

Water samples were collected in February and August 2013, during the rainy and dry seasons, respectively. Thirty-eight samples were collected in total: 19 from rivers, two from dams, 11 at sites with springs, one in a shallow well and five from sites with deep tubular wells part of the Guarani Aquifer System (GAS), which serve as water supply for the population of Faxinal (Figure 1). As shown in the figure, the samples at points 26 and 33 were collected from deep tubular wells used for 
the public water supply network of Faxinal, which also relies on the superficial water supply from the São Pedro River basin, with catchment stations at sampling points 15 and 32 .

Samples were collected using 1.5-L polyethylene bottles properly identified and previously washed with deionized water for decontamination. In order to avoid any interference, the flasks were rinsed five times with the water to be analyzed prior to the collection of the actual sample. The samples were preserved with concentrated nitric acid and packed in ice styrofoam (Souza \& Dersio, 1997).
Subsequently, the water samples were analyzed at the Agricultural Research Support Laboratory (LAPA) of the State University of Londrina. The concentrations of the chemicals elements in the samples were measured using atomic absorption spectrometry (AAS) and induced argon plasma atomic emission spectrometry (ICP-MS), with a focus on the detection of the following inorganic elements: Magnesium (Mg), Copper $(\mathrm{Cu})$, Manganese (Mn), Zinc ( $\mathrm{Zn})$, Chromium (Cr), Nickel (Ni), Aluminum (Al), Lead (Pb), Mercury $(\mathrm{Hg})$, and Cadmium $(\mathrm{Cd})$.

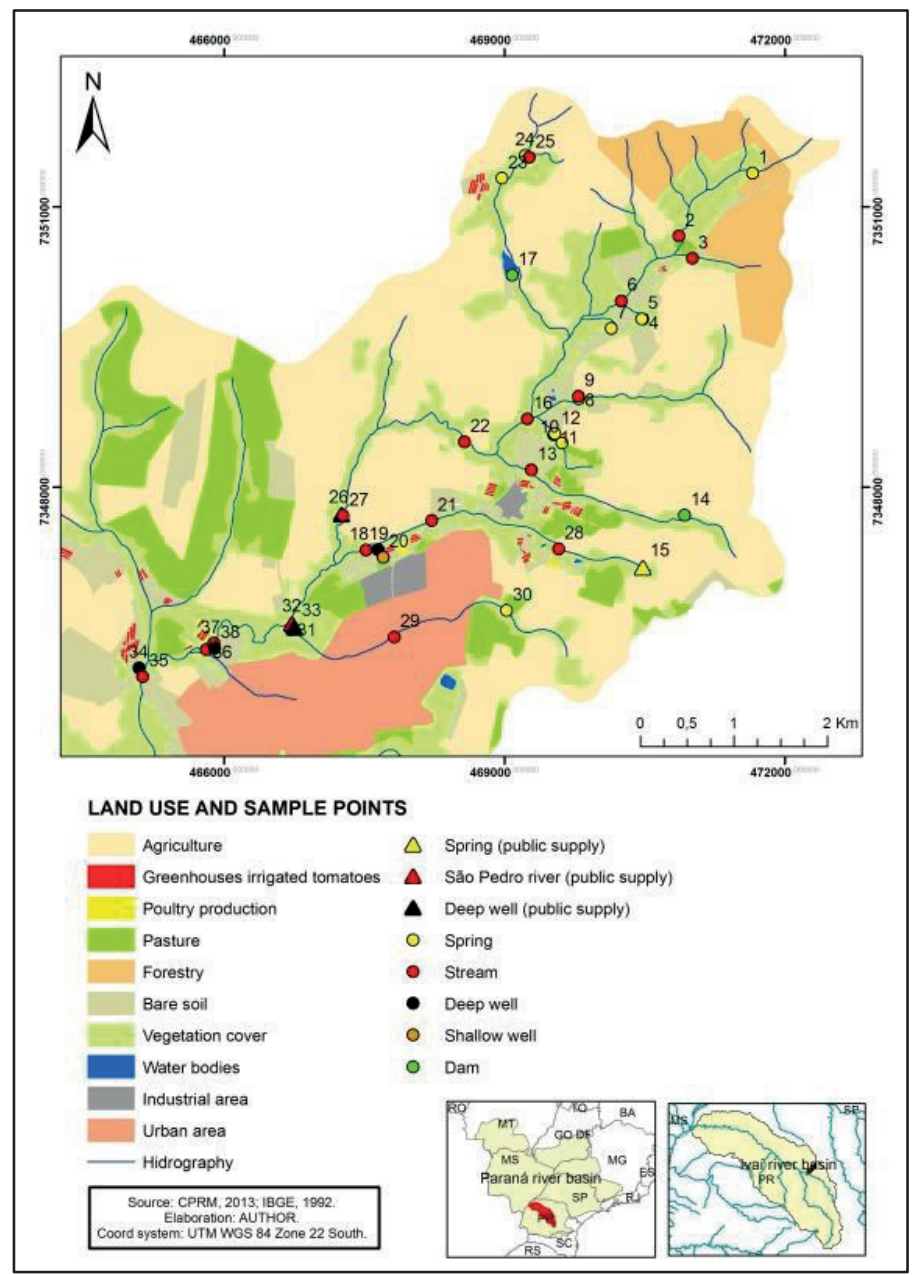

Figure 1. Water sampling points and agricultural activities carried out at the surface of the São Pedro River basin in Faxinal (PR-Brazil). 
It is noteworthy that punctual analyses (15 sites) were performed prior to chemical analyses, which resulted in $\mathrm{pH}$ ranging from 5.9 to 7.7 , with an average value of 6.9 in the basin studied (Justus, 2012), interfering with the solubilization of substances suspended in water.

The concentrations of the chemical substances detected in surface and groundwater of the São Pedro basin during the rainy and dry seasons were compared with the maximum permitted values (MPV) established by Ordinance 2914/2011 (Portaria n. 2914, 2011), which regulates the use and monitoring procedures of drinking water and its potability standards.
Data analysis was carried out using UPGMA hierarchical cluster analysis with standardized Euclidean distance and processed in $\mathrm{R}$ (http: www-r-project.org) using the cluster and heatmap packages.

The levels of chemical elements detected in the water samples are shown in Table 1. It was observed that, in some samples, $\mathrm{Mg}$ and $\mathrm{Al}$ levels exceeded the limits of 0.1 and $0.2 \mathrm{mg} / \mathrm{L}$ respectively, which are the levels allowed by the legislation. Some samples also showed $\mathrm{Hg}$ levels above those recommended by Ministry of Health Ordinance 2914, which is $0.001 \mathrm{mg} / \mathrm{L}$, for water to be considered potable (Portaria n. 2914, 2011). 


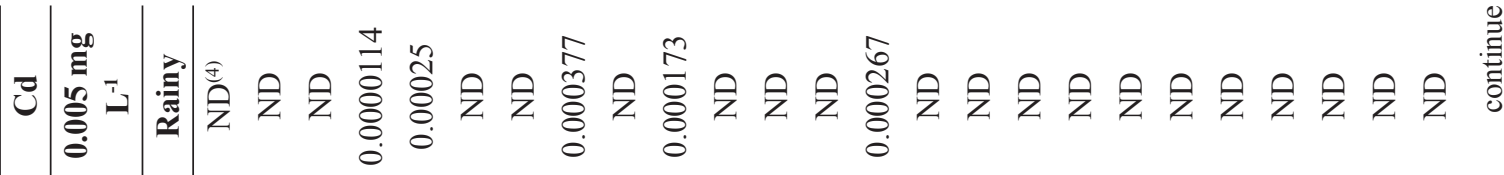

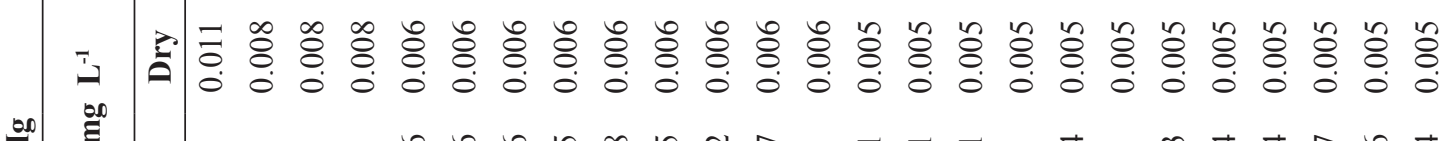
N

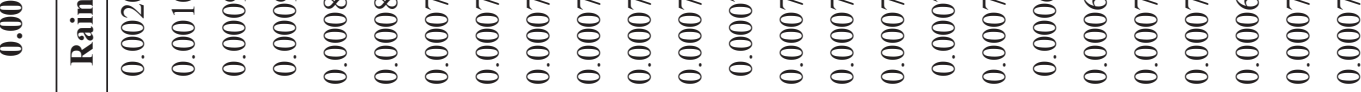

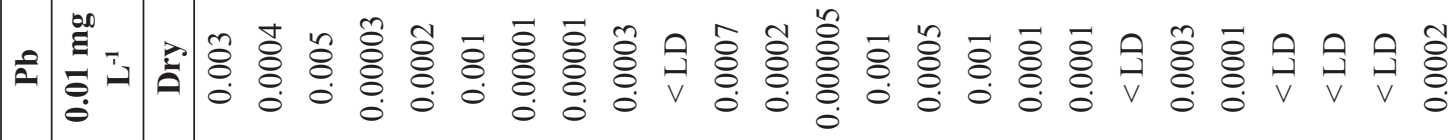

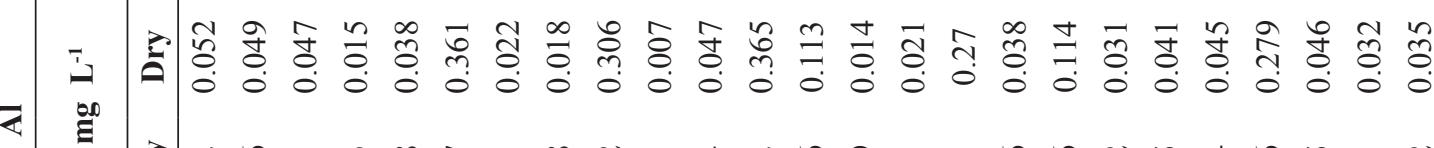

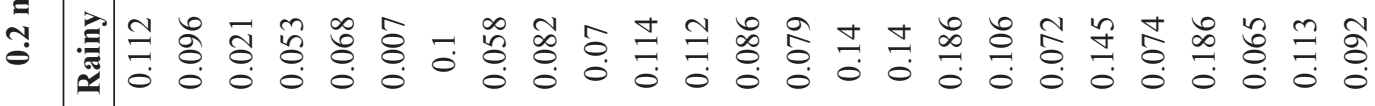

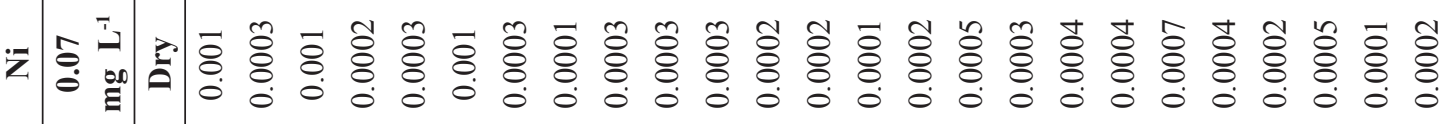
ن

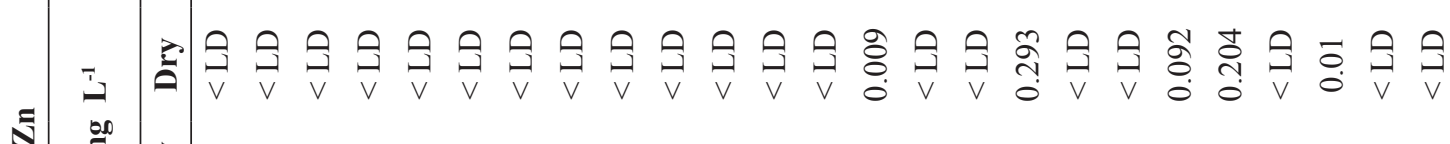

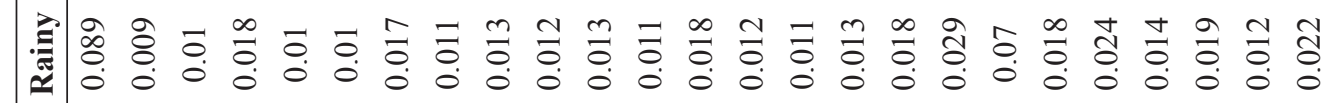

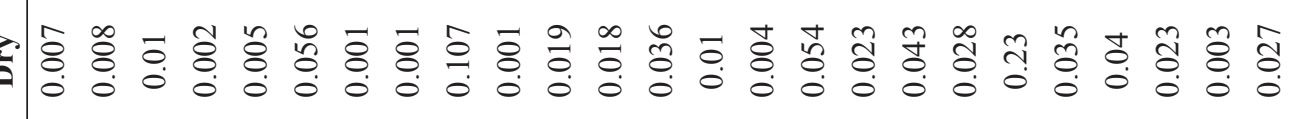

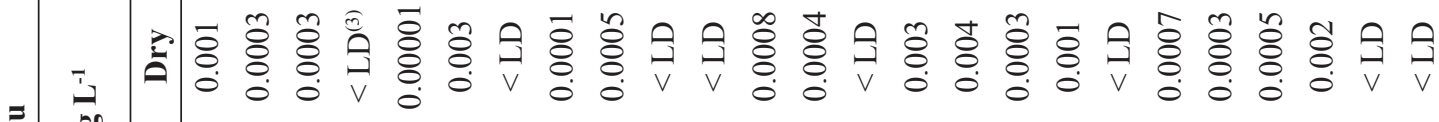

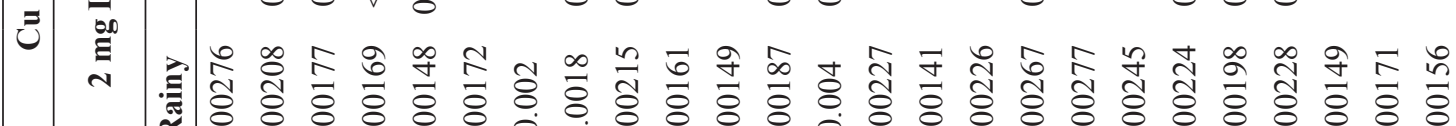

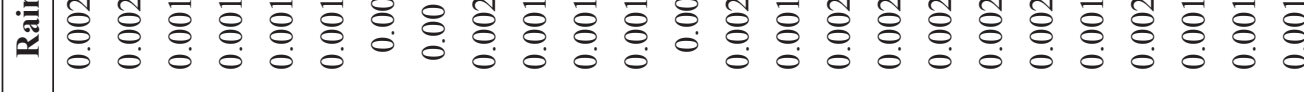

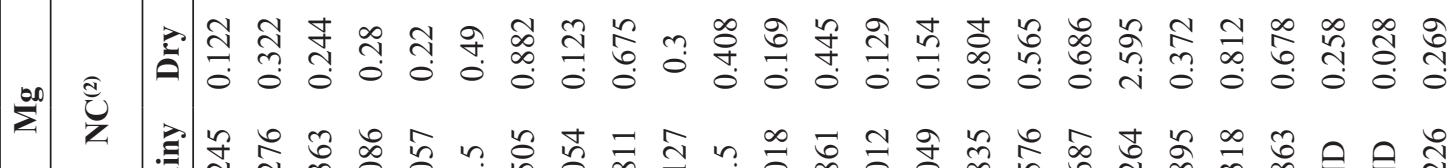

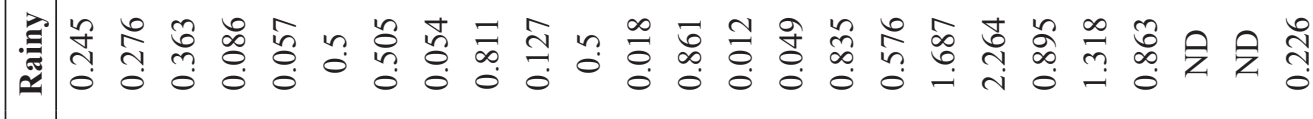

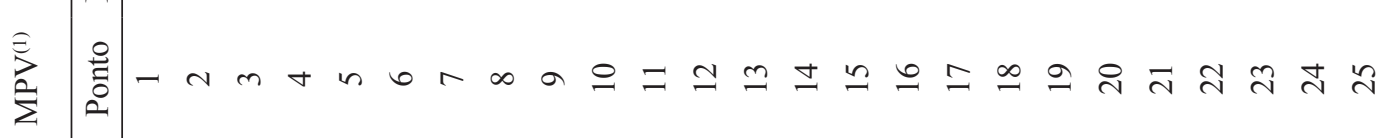


会会会会会会会会会会会会会

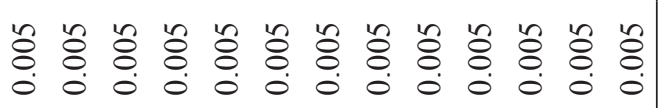

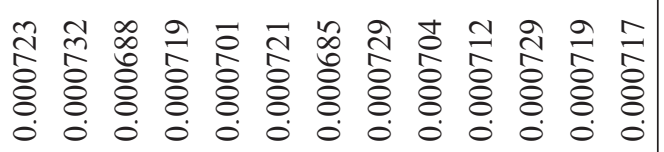

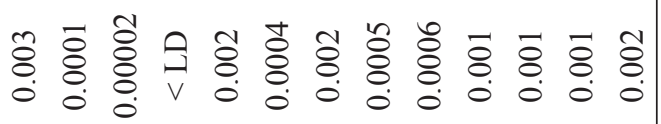

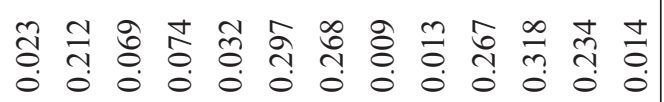

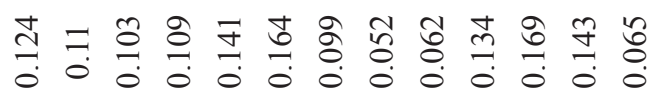

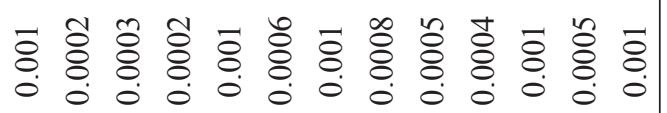

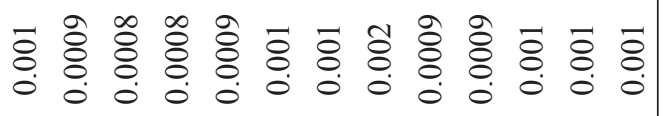

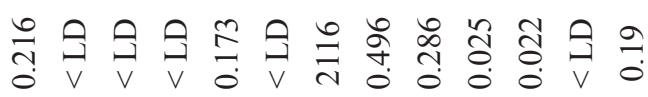

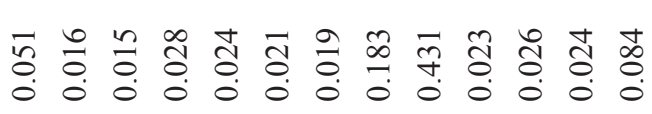
§ै సै

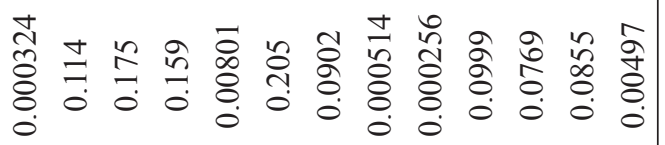

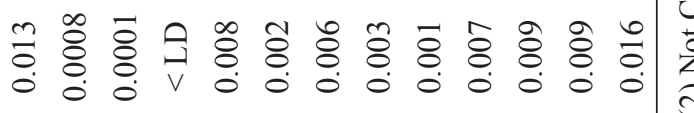

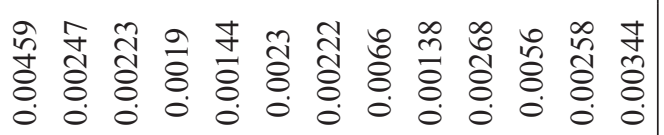

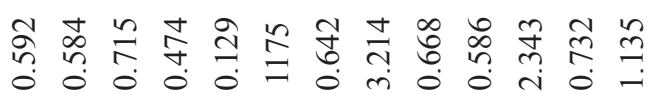

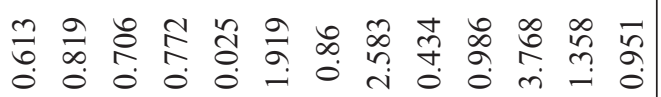
귀 त ते 
In the case of $\mathrm{Mn}$, the major anthropogenic additions to aquatic ecosystems are usually from domestic effluents (Wilbers, Becker, Nga, Sebesvari, \& Renaud, 2014). Nonetheless, the GAS is also known to be covered by the basaltic rocks of the Serra Geral Aquifer System, which are rich in $\mathrm{Mn}$ and contain approximately 50 to $100 \mathrm{ppm}$ (Melo, Uchôa, Dias, \& Barbosa, 2012). Thus, it is expected that this element will be released in its cationic form to the aqueous solution of water bodies as a result of rock weathering. This indicates that the high levels of Mn detected in the analysis may be intrinsic to bedrock composition of the basin and the aquifer framework and not arise as a consequence of anthropogenic activities or the use of agricultural inputs.

Brazilian legislation reports that manganese levels above the recommended would not be so harmful and would be more related to the organoleptic quality of water (Portaria n. 2914, 2011). This shows that there is a need for consistent studies in order to aid in public health policies to improve not only the parameters of the legislation but also the best practices for the use of catchment water and the environmental planning of basins.

Regarding Al, it is naturally occurring in water (Gupta, Gaurav, \& Kumar, 2013) at background concentrations. However, our analytical results suggest that $\mathrm{Al}$ and $\mathrm{Mn}$ levels are above their legally permitted standards in some water samples collected in the dry season. This may be related to variations in the amount of precipitation in the basin, which, in turn, affects the dilution of these elements (Wilbers et al., 2014). An increase in Al levels from rural to urban areas can also be observed, which may be due to liming practices performed in the agricultural area of the basin. A commonly used practice is the employment of calcitic limestone to neutralize aluminum in the soil, which is a potentially toxic compound for crops. Thus, the relatively low amount of $\mathrm{Al}$ found upstream in the rural area of Faxinal can be partially explained by this agricultural management strategy.
Like $\mathrm{Mn}, \mathrm{Al}$ is also a characteristic element of the soil, and may be present in surface waters, taking part in hydrogeochemical cycles. According to Morais, Tauk-Tornisielo, Santos and Ventorini (2012), this element reaches water bodies through surface runoff in the drainage area, when the riparian vegetation is not preserved.

Regarding chemicals that pose a serious risk to human health, $\mathrm{Hg}$ levels above the MPV were found in all samples collected during the dry season and in some of them collected in the rainy season (Portaria n. 2914, 2011). Hg can enter the atmosphere due to traffic pollution and industrial activities and is later deposited in the soil, ultimately entering water bodies through runoff (Wang, Yinglan, Jiang, Fu, \& Zheng, 2015).

According to Fetter (1993), there is little soluble inorganic $\mathrm{Hg}$ under natural conditions. However, some bacteria can convert metallic inorganic $\mathrm{Hg}$ to organic forms such as methylmercury $\left(\mathrm{HgCH}_{3}^{+}\right)$, and chlorine ethylmercury $\left(\mathrm{C}_{2} \mathrm{H}_{5} \mathrm{HgCl}\right)$, the latter being a compound found and used in the manufacture of fungicides.

In the state of Paraná, Rodrigues, Lenzi, Luchese and Rauber (1992) reported levels of mercury higher than the recommended level for drinking water in the waters of the Paraná and Baía rivers around the region of Puerto Rico. The authors highlighted that the gold mining activities were being conducted near the Paraná River, its springs, and those of its tributaries, which pass through industrialized and urban centers, as well as regions of intense agricultural activity. The authors concluded that emergency actions should be implemented to minimize the possible damage to human health.

In Brazil, the use of pesticides containing methylmercury and ethylmercury was banned by the Ministry of Agriculture in 1975 (Ministério do Meio Ambiente [MMA], 2011). However, mercury is a persistent chemical that has remained in the environment and living organisms for a long time (Remor, Sampaio, Model, Falco, \& Prudente, 2018). 
Considering that the area studied is located in the Paraná River basin and that mercury persists in the environment, the probable source of contamination of aquatic systems can be associated with industrial waste or inputs used in different agricultural crops in the region.

The multivariate cluster analysis showed five different sample groups, grouped according to the similarity of the variables analyzed in the study area (Figure 2). Group 4 comprised most of the sampling points located in the agricultural area of Faxinal. This group consists mainly of sites with springs and is also characterized by the points where the highest levels of $\mathrm{Hg}$ were found both in the rainy and dry seasons. On the other hand, sites that were closest to the urban area constituted Groups 1, 2, 3, and 5, where the highest levels of $\mathrm{Mn}$ and $\mathrm{Al}$ were found and where the water was collected mainly from the river (Figure 2).

\section{Cluster Dendrogram}

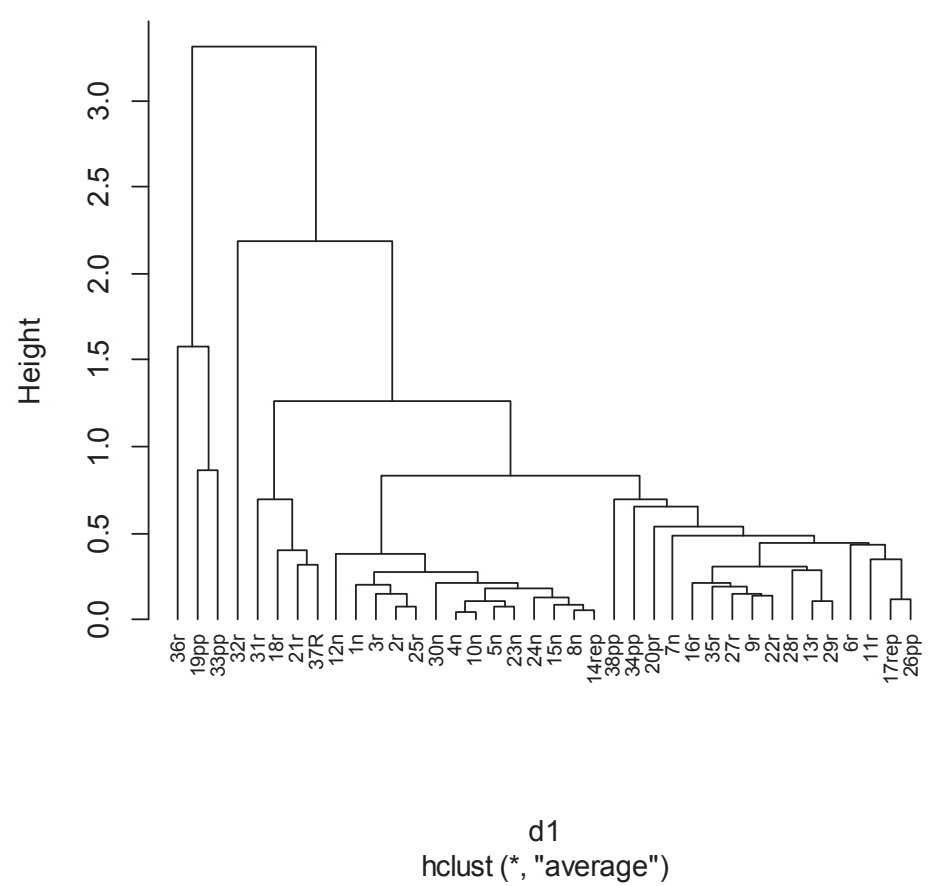

Figure 2. Multivariate cluster analysis: Groups formed by similarities of variables from sampled points. Notes: Spring (n), River (r), Dam (rep), Deep well (pp), and Shallow well (pr).

According to the Brazilian legislation, Al, $\mathrm{Zn}$, and $\mathrm{Mn}$ are references for the organoleptic standard of water potability, representing the set of parameters responsible for the sensory stimuli that affect the acceptance for human consumption, but that do not necessarily imply a risk to health, while
$\mathrm{Cd}, \mathrm{Cu}$, and $\mathrm{Hg}$ are considered elements that can pose a risk to human health (Portaria n. 2914, 2011).

One aspect that should be taken into consideration is the contamination of fish, since the contaminants lead to toxic effects in the contaminated organisms, with consequences for the environment (Vieira et 
al., 2016). This perspective should be addressed in future studies, given the use of water bodies in the region for fishing, fish consumption, and recreation purposes. Furthermore, considering that agricultural activities are the predominant practices around the sampled points, it is necessary to investigate not only if the occupation and use of these farmlands may be altering the levels of $\mathrm{Hg}$ detected in the adjacent aquatic environment but also establish periodic monitoring efforts to evaluate the behavior of this element in the ecosystem throughout the seasonal cycle.

Moreover, it is important to highlight that the presence of Organophosphates, Methylcarbamates, Chloroacetamides, Triazoles, Pyrethroids, Acetamides and Pyrazoles were detected in the Paraná River basin. The presence of these compounds is associated with the use of pesticides in irrigated rice crops. Carbofuran was the most abundant compound, along with other herbicides that are often used in this region, such as Atrazine (Chicati, Nanni, \& Cézar, 2012).

Since $\mathrm{Hg}$ is an element with potential to cause damage to living organisms, the consequent reduction of exposure is the only effective way to reduce the environmental risk as well as its harmful effects on human health. Future investigations should be carried out during the dry season in order to better understand the seasonal cycle of this compound within the agricultural area of Faxinal to allow for a better management of the surface region of the São Pedro river basin.

In general, the levels of $\mathrm{Mn}, \mathrm{Al}$, and $\mathrm{Hg}$ above the MPVs set by the Brazilian Ministry of Health Ordinance 2914/2011 seem not to compromise the water quality in the surface region of the São Pedro river basin, especially because these can be a result of the intrinsic geology of the area, which may be interfering with the concentration of these substances rather than indicating an actual scenario of pollution from anthropogenic activity. This is further supported by the fact that high levels were not detected in all the sampling sites.
However, the concentrations of the chemical substances $\mathrm{Mn}, \mathrm{Al}$ e $\mathrm{Hg}$ detected in the surface and groundwater from the São Pedro river basin during the rainy and dry seasons showed levels above those permitted by the Brazilian legislation established to ensure water quality for human consumption. This fact raises concern and highlights the need for further studies, aimed at the detection of possible sources of contamination in these waters, as well as the establishment of a continuous monitoring network that is able to alert to the potential risks to human health year-round, thus contributing to the environmental planning of the basin.

\section{Acknowledgements}

We would like to thank the "Coordenação de Aperfeiçoamento de Pessoal de Nível Superior" for their financial support and the "Laboratório de Apoio a Pesquisas Agropecuárias da Universidade Estadual de Londrina" for conducting all the laboratory analyses.

\section{References}

Chiarello, M., Graeff, R. N., Minetto, L., Cemin, G., Schneider, V. E., \& Moura, S. (2017). Determinação de agrotóxicos na água e sedimentos por HPLCHRMS e sua relação com o uso e ocupação do solo. Química Nova, 40(2), 158-165. doi: 10.21577/01004042.20160180

Chicati, M. L., Nanni, M. R., \& Cézar, E. (2012). Chemical contamination of water in irrigated rice on Paraná State, Brazil. Semina: Ciências Agrárias, 33(4), 1455-1462. doi: 10.5433/1679-0359.2012v33 n4p 1455

Fetter, C. W. (1993). Contaminant hydrogeology (2nd ed.). New York: Macmillan Publishing Company.

Freire, R., Schneider, R. M., Hernandes de Freitas, F., Bonifácio, C. M., \& Granhen Tavares, C. R. (2012). Monitoring of toxic chemical in the basin of Maringá stream. Acta Scientiarum Technology, 34(3), 295302. doi: 10.4025/actascitechnol.v34i3.10302

Gupta, N., Gaurav, S. S., \& Kumar, A. (2013). Molecular basis of aluminium toxicity in plants: a review. American Journal of Plant Sciences, 4(12), 21-37. doi: 10.4236/ajps.2013.412A3004 
Justus, C. M. (2012). Utilização do SIG para o monitoramento de alguns parâmetros físicoquímicos das águas superficiais da bacia hidrográfica do rio São Pedro em Faxinal - PR. Geoingá: Revista do Programa de Pós-Graduação em Geografia, 4(2), 26-39.

Melo, V. F., Uchôa, S. C. P., Dias, F. O., \& Barbosa, G. F. (2012). Doses de basalto moído nas propriedades químicas de um Latossolo Amarelo distrófico da savana de Roraima. Acta Amazonica, 42(4), 471476. doi: 10.1590/S0044-59672012000400004

Ministério do Meio Ambiente (2011). Perfil do gerenciamento de mercúrio no Brasil, incluindo seus resíduos. Brasília: MMA.

Morais, E. B., Tauk-Tornisielo, S. M., Santos, A. A. O., \& Ventorini, S. E. (2012). Distribuição de metais nas águas do rio Cabeça, tributário na bacia do rio Corumbataí, SP. Holos Environment, 12(2), 147167. doi: 10.14295/holos.v12i1.4517

Portaria n. 2914, de 12 de dezembro de 2011. Dispõe sobre os procedimentos de controle e de vigilância da qualidade da água para consumo humano e seu padrão de potabilidade. Diário Oficial da União, Brasília.

Remor, M. B., Sampaio, S. C., Model, K. J., Falco, T. D., \& Prudente, V. H. R. (2018). Mercury in the sediment of Pelotas river basin, Brazil. Engenharia Agrícola, 38(1), 117-123. doi: 10.1590/1809-4430
Rodrigues, B. A., Lenzi, E., Luchese, E., \& Rauber, T. (1992). Níveis de concentração de mercúrio total nas águas dos rios Paraná e Baía - Região de Porto Rico. Acta Limnologica Brasiliensia, 4(1), 255-260. doi: 10.5935/1984-6835.20160017

Souza, H. B., \& Dersio, J. C. (1997). Guia técnico de coleta de amostras de água. São Paulo: CETESB.

Vieira, C. E. D., Costa, P. G., Lunardelli, B., Oliveira, L. F., Cabrera, L. da C., Risso, W. E.,... Martinez, C. B. R. (2016). Multiple biomarker responses in Prochilodus lineatus subjected to short-term in situ exposure to streams from agricultural areas in Southern Brazil. Science of the Total Environment, 542, 44-56. doi: 10.1016/j.scitotenv.2015.10.071

Wang, G., Yinglan, A., Jiang, H., Fu, Q., \& Zheng, B. (2015). Modeling the source contribution of heavy metals in surficial sediment and analysis of their historical changes in the vertical sediments of a drinking water reservoir. Journal of Hydrology, 520, 37-51. doi: 10.1016/j.jhydrol.2014.11.034

Wilbers, G.-J., Becker, M., Nga, L. T., Sebesvari, Z., \& Renaud, F. G. (2014). Spatial and temporal variability of surface water pollution in the Mekong Delta, Vietnam. Science of the Total Environment, 485-486, 653-665. doi: 10.1016/j.scitotenv.2014.03.049 